\title{
A TRADUÇÃO COMO UM ESPAÇO ALTERNATIVO PARA AÇÃO POLÍTICA ${ }^{1}$
}

\author{
Mona Baker \\ University of Manchester \\ Manchester, UK
}

Tradução de:

Cristiane Roscoe-Bessa, Flávia Lamberti \& Janaína Araujo Rodrigues

Universidade de Brasília Brasília, Distrito Federal, Brasil

\section{Introdução}

Uma suposição, ainda não examinada, que continua sustentando as discussões sobre tradução e interpretação, especialmente entre leigos, é a ideia de que os indivíduos que traduzem textos e enunciados são neutros, desinteressados, criaturas apolíticas, meros condutores que não tomam posicionamento e não têm participação no resultado das interações que mediam. Entretanto, numerosos exemplos da vida real continuam a mostrar que tradutores e intérpretes não são apolíticos, que muitos têm fortes convicções sobre

\footnotetext{
${ }^{1}$ Artigo publicado na revista Social Movement Studies: Journal of Social, Cultural and Political Protest em 2013. A presente tradução foi autorizada para ser publicada em português pela Editora Taylor \& Francis (Taylor \& Francis Ltd, < http://www.tandfonline. com $>$ ) e pela autora Mona Baker, aos quais agradecemos imensamente. Referência bibliográfica completa do artigo original: BAKER, Mona. Translation as an Alternative Space for Political Action. Social Movement Studies: Journal of Social, Cultural and Political Protest, v. 12, n. 1, p. 23-47, 2013.
} 
os erros e acertos de eventos (políticos) nos quais fazem parte profissionalmente como tradutores e intérpretes. ${ }^{2} \mathrm{Na}$ verdade, como este artigo demonstra, vários grupos de tradutores e intérpretes estão de alguma forma envolvidos ativamente em ações coletivas que tentam desafiar o status quo político. Assim, eles se afastaram de uma longa tradição de posicionar-se apenas de forma neutra, como profissionais não comprometidos que se colocam em um espaço "intermediário" entre culturas e divisões políticas.

Sem considerar essas formas recentes de ação coletiva, defendo que a tradução não media encontros culturais que existem fora de seu âmbito, mas sim participa na produção destes encontros. A tradução não reproduz textos, mas constrói realidades culturais ao intervir no processo de narração e renarração que constitui todos os encontros e que essencialmente constrói o mundo para nós. Não se trata de um ato inocente de mediação desinteressada, mas um importante meio de construir identidades e configurar os moldes de qualquer encontro.Ao adotar uma abordagem narrativa da interação, elaborada em conexão com a tradução em trabalhos anteriores (BAKER, 2006a, 2006b, 2009, 2010), parto do princípio de que as histórias que contamos e recontamos, incluindo aquelas recontadas por meio de traduções, constituem um local onde exercitamos nossa atividade e, nesse sentido, elas são, em última análise, uma ferramenta para mudar o mundo. Elas nos permitem elaborar nossa identidade individual e coletiva e negociar as condições da história em que nos encontramos, seja como leigos, profissionais em um determinado domínio ou ativistas que exploram de forma consciente suas habilidades profissionais para efetuar uma mudança em âmbito local ou global.

${ }^{2}$ A Declaração de Granada, lançada no fim de um fórum denominado "Social Activism in Translation and Interpreting", realizado em Granada, em abril de 2007, rejeita a visão comum do tradutor "como um veículo neutro entre ideias e culturas". Ver: < http://www. translationactivism.com/Manifest.html >. (Acesso em: 8 ago. 2011). 


\section{Tradução, narração e ação coletiva}

Hernadi (1980/1981, p. 199) atribui nossa necessidade de narrar a duas motivações principais: "autoasserção" e "compromisso de autotranscendência". No atual contexto, destaca-se a segunda motivação. O "compromisso de autotranscendência" nos leva a narrar para "substituir a indiferença pelo comprometimento social ou cósmico ou para mudar o mundo ou a nós mesmos" (HERNADI, 1980/1981). A narrativa é geralmente associada ao impulso moralizante dos seres humanos que, em parte, faz dela uma interessante abordagem para lidar com as formas de ativismo em geral, incluindo as formas de ação coletiva no mundo da tradução e interpretação.

Nas seções que se seguem, examino a gênese, o posicionamento e as estratégias prefigurativas de grupos de tradutores e intérpretes ativistas que são, por fim, motivados não por qualquer atributo intrínseco ou compartilhado por indivíduos que formam cada grupo - esses grupos não se envolvem em políticas de identidade - mas por uma identificação com a história ou conjunto de 'histórias' que fornecem um norte para suas atividades políticas. Essas histórias estão enraizadas em narrativas mais amplas de justiça global, e não em narrativas de aspirações nacionalistas, por exemplo, ou crenças religiosas. Neste sentido, os grupos em questão pertencem ao que Tarrow descreve como "a nova geração de ativistas pela justiça mundial" (2006, p. 46), que se tornaram mais visíveis desde os eventos em Seattle em 1999. Eles também são 'ativistas externos' (TARROW, 2006, p. 45) que desafiam instituições existentes em vez de tentar mudá-las internamente. De fato, a maioria rejeita qualquer forma de institucionalização. Em geral, as narrativas a que esses grupos subscrevem e tentam promover globalmente por meio de seus atos de tradução e de envolvimento com várias formas de política prefigurativa objetivam substituir a indiferença, nas palavras de Hernadi, por um compromisso para mudar todo o conjunto de relações que define a atual ordem mundial. Um dos maiores e mais visíveis grupos, o Babels, alinha-se explicitamente com o 
Fórum Social Mundial, e seu lema "Um Outro Mundo é Possível" indica que seus membros estão engajados ativamente em renarrar o mundo para além da fronteira linguística e cultural.

Espero demonstrar neste artigo que esses grupos operam de forma muito similar a outros movimentos globais de ação coletiva e que a maioria está condizente com os critérios de "movimentos autônomos" delineados por Flesher Fominaya (2007, p. 337-341). Entretanto, ao contrário da maioria dos outros movimentos globais e autônomos, eles possuem um forte caráter "profissional", pois muitos membros (possivelmente a maioria) são tradutores e/ ou intérpretes profissionais ou estudantes de tradução; cada grupo intitula-se claramente "tradutores" e a raison d'être de cada grupo está fortemente ligada à habilidade de seus membros de oferecer mediação linguística. Os membros de todos os grupos aqui analisados usam suas habilidades linguísticas para expandir o espaço e as oportunidades narrativas de resistência e para dar poder às vozes invisibilizadas pelo poder global do inglês e pelas políticas das línguas. Ao fazer isso e ao questionar uma antiga e poderosa tradição de enfatizar a neutralidade dos tradutores na linguagem comum, profissional e acadêmica, esses ativistas se posicionam dentro de um espaço que não é totalmente compreendido e apreciado pelas comunidades de ativistas com as quais eles interagem, o que é evidente na tensão contínua entre o Babels e os organizadores do Fórum Social Mundial, tampouco totalmente aceito por seus colegas profissionais, que geralmente veem este envolvimento político concreto com desconfiança e preocupação.

Além de dar voz e de ampliar o espaço narrativo, é importante observar que esses grupos reconhecem que a linguagem e a tradução constituem um espaço de resistência, um meio de inverter a ordem simbólica (MELUCCI, 1996). O funcionamento e as práticas de grupos, como o Babels e o Tlaxcala, discutidos abaixo, são elaborados de forma consciente para questionar e narrar as fronteiras como permeáveis e porosas. O uso de linguagem híbrida, a depreciação deliberada do inglês, o constante rearranjo da ordem e do espaço atribuídos às diferentes línguas em seus websites $\square$ todas 
essas atividades fazem parte tanto de pautas políticas quanto da mediação linguística de textos e enunciados produzidos por terceiros, na qualidade de tradutores e intérpretes.É essa prática de política prefigurativa, uma característica central de movimentos autônomos (FLESHER FOMINAYA, 2007), que os distingue mais claramente dos outros grupos de tradutores que oferecem suporte linguístico para organizações humanitárias e para uma variedade de boas causas. Em termos de discurso e de comportamento, eles praticam os princípios que apoiam, ao invés de permanecer dentro dos rígidos limites do papel profissional e de atribuir o trabalho político para outros, ao mesmo tempo em que defendem esses princípios e possibilitam que outros os adotem em uma grande variedade de línguas. Eles ainda aplicam esses princípios no presente, frequentemente de maneira inovadora, ao invés de buscar usá-los em algum momento no futuro, quando determinados objetivos políticos tangíveis e bem definidos já teriam sido alcançados.

\section{Tradução e interpretação como forma de ação coletiva}

Como a nova geração de ativistas pela justiça mundial (TARROW, 2006), os grupos analisados aqui tendem a depender profundamente da tecnologia da Internet para se comunicar e coordenar seus trabalhos e, em alguns casos, para circular suas traduções. Com recursos limitados e membros espalhados por diversos lugares, esses grupos conseguem mobilizar-se de modo eficaz no ambiente virtual graças às novas tecnologias de mídia e da Internet. Em graus variados, eles possuem perfil internacional, atraindo membros de todos os seis continentes, embora operem e sejam mantidos principalmente da Europa, talvez porque tradutores e intérpretes com base na Europa tenham acesso melhor e menos restrito aos recursos, e têm condição de dedicar mais tempo para o trabalho político do que, digamos, seus colegas de Camarões, Irã ou China. Tarrow (2006) relata uma desigualdade geográfica similar em todos os movimentos globais; parece que mesmo no ati- 
vismo "os mais ricos e bem conectados cidadãos do norte têm uma vantagem líquida, maiores recursos financeiros e organizacionais e vivem mais próximos das sedes de grandes instituições internacionais" (p. 44). ${ }^{3}$

Com base no tipo de material traduzido e nos locais em que as traduções são publicadas, é possível identificar dois tipos gerais de comunidades de ativistas de tradutores e intérpretes: (1) grupos cujas atividades giram principalmente em torno da seleção, tradução e disseminação de material escrito por meio de websites e listas de e-mails; e (2) grupos que trabalham na comunidade e/ou dentro de fóruns coletivos - principalmente o Fórum Social Mundial - e cujas atividades consistem predominantemente em interpretar a interação oral em eventos específicos. Nos dois casos, ao contrário de muitos outros grupos de ativistas que traduzem material político com o objetivo de realizar mudança, tais como a comunidade que criou o Tahrir Documents em março de $2011^{4}$, todos os grupos analisados aqui se identificam como tradutores e intérpretes e, portanto, posicionam-se explicitamente dentro do mundo profissional e acadêmico da tradução, dando origem a certas tensões que explorarei posteriormente neste artigo. Esse posicionamento é indicado nos nomes dos grupos (Translators for Peace - Tradutores pela Paz; Translators United for Peace (TUP) - Tradutores Unidos pela Paz; Translator Brigades - Brigada de Tradutores; Tlaxcala: The International Network of Translators for Linguistic Diversity - Tlaxcala: Rede Internacional de Tradutores para Diversidade Linguística; ECOS, traductores e interpretes por la solidaridad - tradutores e intér-

\footnotetext{
${ }^{3}$ Ver também Atton (2003, p. 8), que confirma que a concentração do Indymedia IMC (Centro de Mídia Independente) "permanece maior nos EUA [...] e Europa [...] Outras regiões têm uma representação muito menor".

${ }^{4}$ De acordo com a seção "About us", o Tahrir Documents "é um esforço contínuo para registrar e traduzir documentos ativistas sobre a revolução egípcia de 2011 e suas consequências". Os materiais são coletados nas manifestações na Praça Tahrir, no Cairo, e publicados na íntegra ao serem traduzidos para o inglês, juntamente com as digitalizações dos documentos originais.O projeto não é ligado a qualquer organização política egípcia ou outra. Ver: http://tharirdocuments.org/about/ (Acesso em: 9 mar. 2012).
} 
pretes pela solidariedade). Isso fica ainda mais claro na narrativa de cada grupo, principalmente na seção “About Us” (Sobre Nós) dos respectivos websites. Por exemplo, os Tradutores pela Paz se definem como "uma livre associação de tradutores de todos os países e nacionalidades" e o Babels se descreve como "uma rede internacional de intérpretes e tradutores voluntários" 5 . Além desses dois tipos mais gerais, podemos também distinguir os grupos com uma pauta restrita e contrária à guerra (Tradutores pela Paz e TUP) e aqueles com uma pauta mais ampla a favor de uma mudança política radical (Babels, ECOS, Tlaxcala e Brigada de Tradutores).

\section{Tipo 1: Foco em Traduções Escritas}

O primeiro tipo de comunidade ativista examinado aqui dedicado à tradução e à disseminação de textos escritos é, por exemplo, Traduttori par la Pace - Tradutores pela Paz - (fundado na Itália em 1999), TUP (fundado no Japão em março de 2003), Tlaxcala (fundado "virtualmente" em dezembro de 2005, sem nenhuma nacionalidade sede declarada) e Brigada de Tradutores (fundado como parte da "onda de solidariedade ao 15- $\mathrm{M}^{6}$ e ao Occupy Movement" em setembro de 2011). Os dois primeiros adotam uma pauta restrita pela paz e parecem ter sido criados em resposta a guerras específicas: Kosovo, no caso dos Tradutores pela Paz, e Iraque, no caso do TUP.O estatuto do grupo Tradutores pela Paz declara:

\section{A Associação foi criada no contexto histórico da guerra ini- ciada pelos países pertencentes à aliança da Otan [sic] con- tra a Sérvia em um esforço de responder à falta e distorção de informação que os promotores [sic] para ser o resultado}

\footnotetext{
5 Ver: < http://web.tiscali.it/traduttoriperlapace/ > e < http://www.babels.org/spip. php?rubrique2 > (Acesso em: 9 mar. 2012).

${ }^{6} \mathrm{O}$ protesto que começou na Espanha em 15 de março de 2011. A declaração indica indiretamente a origem espanhola do grupo, mas no site não há tentativa de indicar um contexto geográfico específico.
} 
da parede propagandística presente nos países da Aliança Ocidental e na Sérvia. ${ }^{7}$

O site declara que o grupo tem como objetivo "publicar, na medida do possível, em todas as línguas e por qualquer canal, toda mensagem contra as guerras em geral e, de forma específica, contra o uso de guerras como meio de resolver disputas internacionais". Assim, o grupo se define essencialmente como uma coalizão de ativistas contra a guerra.O TUP possui uma pauta similar, mas seu website ainda não oferece uma interface em inglês (Figura 1), porém um membro do grupo (Mari Oka, Universidade de Kyoto) confirma que a página "Sobre Nós" descreve o grupo como comprometido a "fazer uma contribuição para criar um mundo pacífico sem guerra"8 (comunicação pessoal, 2 de novembro de 2011).

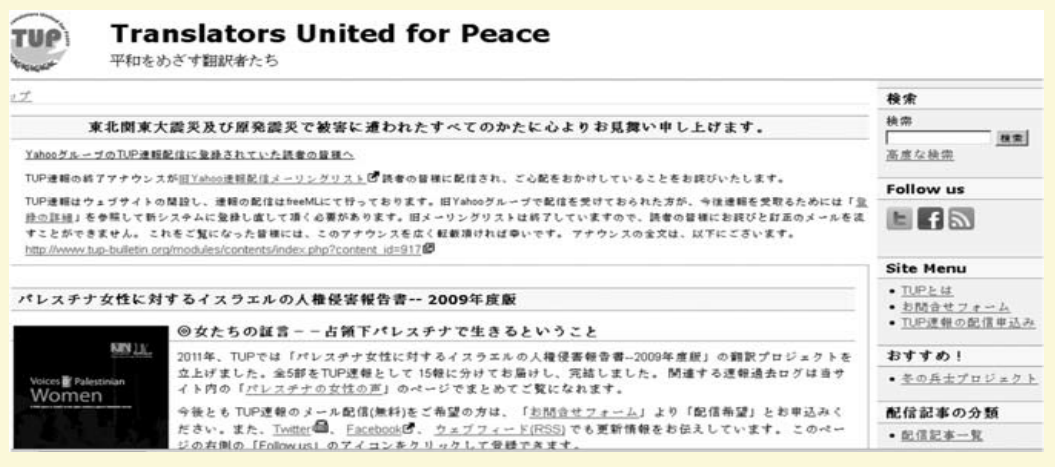

Figura 1.Website do Tradutores Unidos pela Paz

Os grupos que adotam uma pauta pela paz, como os Tradutores pela Paz e o TUP, costumam estar restritos a um cenário geográfico específico (Itália, Japão) e centralizam a promoção de narrativas

\footnotetext{
$7<$ http://web.tiscali.it/traduttoriperlapace/ > . (Acesso: 9 mar. 2012).

$8<$ http://www.tup-bulletin.org/modules/main/index.php?content_id $1 / 41>$. (Acesso: 9 mar. 2012).
} 
antiguerras dentro de espaços locais, especialmente ao traduzir e disseminar textos que elaboram essas narrativas antiguerras para os membros de suas comunidades imediatas. $\mathrm{O}$ grupo Tradutores pela Paz trabalha predominantemente com o italiano e outras línguas, principalmente o inglês. O inglês é a única outra língua que aparece na interface do site, em contraste com outros grupos, como Babels, Tlaxcala e Brigada de Tradutores, que oferecem em seus websites interfaces e/ou conteúdos traduzidos em diversas línguas. O grupo TUP trabalha apenas com o japonês e afirma em seu site que essas traduções são destinadas a "causar impacto na política, nos cidadãos e nos meios de comunicação japoneses" ". Os dois grupos, Tradutores pela Paz e TUP, são relativamente pequenos - com cerca de 25 membros no caso do TUP (Mari Oka, comunicação pessoal, 2 de novembro de 2011) e não mais que 35 ou 40 no caso do Tradutores pela Paz (com base na lista de membros disponível no site entre 2005 e 2012).Além de tradução de textos escritos, o grupo TUP às vezes oferece intérpretes voluntários a palestrantes que criticam a guerra em visita ao Japão.De todos os grupos analisados neste artigo, esses dois são os menos integrados ao movimento global pela justiça e os mais distantes da definição de "movimentos autônomos", tal como discutido em Flesher Fominaya (2007), entre outros.

O Tlaxcala e o Brigada de Tradutores não se consideram coalizões contra a guerra e não tentam influenciar um público delimitado geograficamente. O grupo Brigada de Tradutores se descreve como "uma rede de ativistas e tradutores internacionais que buscam mudança global" e como "uma ideia, a ideia de que, visto que os diferentes problemas enfrentados em cada país são causados por uma crise global do sistema, as soluções deveriam vir do diálogo e da união dos cidadãos de todo o mundo" ${ }^{10}$ (grifo meu). O grupo Tlaxcala se descreve como uma "rede internacional de tradutores

\footnotetext{
${ }^{9}$ Agradeço a Mari Oka por me fornecer uma tradução para o inglês das seções relevantes do site.

${ }^{10}<$ http://translatorbrigades.wordpress.com/about/ >. (Acesso: 9 mar. 2012).
} 
pela diversidade linguística" ${ }^{11}$ e mostra isso claramente em sua pauta radical e militante (grifo meu). Enquanto outros grupos têm "estatutos" e "constituições", o Tlaxcala tem um "manifesto" que descreve o seu trabalho e objetivo em uma linguagem revolucionária:

\begin{abstract}
Os tradutores do Tlaxcala são antimilitaristas, antiimperialistas e se opõem à globalização corporativa "neoliberal". Aspiram à paz e à igualdade entre todas as línguas e culturas. Não creem na guerra de civilizações e nem na atual cruzada imperial contra o terrorismo. ${ }^{12}$
\end{abstract}

No final do manifesto, há um chamado à luta: "Tradutores e intérpretes de todas as línguas, conectem-se e unam-se! Webmasters e blogueiros de todas as cores do arco-íris que compartilham de nossas preocupações, contatem-nos!"

O "manifesto" do Tlaxcala é um tratado amplo sobre a política das línguas em geral e do inglês em particular, que implementa uma narrativa de um mundo intrinsicamente conflituoso, onde diferentes impérios subjugaram nações e grupos mais fracos e reforçaram essa subjugação por meio de suas línguas desde tempos mais remotos.Os membros do Tlaxcala são idealizados como um tipo específico de protagonista, como guerreiros com um papel político particular para representar dentro dessa narrativa:

Os tradutores do Tlaxcala creem na alteridade, na boa vontade de considerar o ponto de vista de outros e, por isso, se comprometem a tornar o inglês uma língua não imperial, publicando em todas as línguas possíveis (inclusive em inglês) as vozes de escritores, pensadores, chargistas e ativistas que redigem hoje textos originais em línguas cuja influência avassaladora do império [sic] não permite que elas

$11<$ http://www.tlaxcala-int.org/ >. (Acesso: 11 ago. 2011).

$12<$ http://www.tlaxcala-int.org/manifeste.asp?lg_aff $1 / 4 \mathrm{en}>$. (Acesso: 11 ago. 2011). 
sejam ouvidas. Do mesmo modo, os tradutores do Tlaxcala permitem que não falantes do inglês conheçam as ideias de escritores anglófanos situados à margem ou publicados em meios de comunicação menores e difíceis de encontrar.

A língua inglesa, como um aparato institucional do conhecimento, é hoje uma estrutura de poder global que apresenta as línguas e culturas do mundo à sua imagem e semelhança, sem pedir permissão ao mundo que intenciona representar. Os tradutores do Tlaxcala estão convencidos de que é possível derrotar os senhores do discurso e ambicionam abalar essa estrutura para que o mundo consiga ser multipolar e multilinguístico, possuidor de uma diversidade semelhante à da própria vida. ${ }^{13}$

Embora o Tlaxcala se restrinja a traduções escritas divulgadas via internet, ele está mais bem inserido na cultura do ativismo transnacional do que os grupos antiguerras analisados acima e sinaliza seu alinhamento com os princípios do Fórum Social Mundial de várias maneiras - diretamente, em seu manifesto, e indiretamente por meio das (várias) escolhas contínuas da seleção de textos para serem traduzidos, do modo como o grupo configura sua própria estrutura como uma rede de indivíduos e organizações e da forma como projeta a(s) relação(ções) entre as línguas de partida e de chegada nas traduções.O mesmo é válido para o recém-fundado grupo Brigada de Tradutores, cuja declaração da missão sinaliza um posicionamento semelhante:

Somos provenientes de diferentes contextos, mas temos uma preocupação comum com a desigualdade mundial e o sofrimento humano. Advogamos os princípios de solidariedade, a autoria coletiva e a democracia direta. Acreditamos que o nosso uso criativo das redes sociais e o compromisso de traduzir servirão para propagar ideias valiosas e dar

$13<$ http://www.tlaxcala-int.org/manifeste.asp?lg_aff $1 \frac{1}{4} \mathrm{en}>$. (Acesso: 11 ago. 2011). 
poder às lutas por justiça ao criar e reforçar laços entre movimentos sociais em todo o mundo. ${ }^{14}$

O grupo Brigada de Tradutores também se insere em movimentos de justiça global ao concentrar boa parte de sua energia em traduzir chamadas para a ação em âmbito mundial, como também o conteúdo do Adbusters "para criar um público internacional de leitores para essa valiosa publicação"1514. A página "Sobre Nós" declara que o grupo trabalha com "vinte línguas", mas não está claro quais são essas e nem se a direção da tradução é restrita, por exemplo, do inglês para outras línguas, mas não vice-versa. Parece ser assim no caso do material traduzido do Adbusters, que é hospedado fora do site principal e acessado por meio de um link na página "Sobre Nós". A direção da tradução nesse caso parece ser estritamente do inglês para outras línguas (Figura 2). ${ }^{16}$

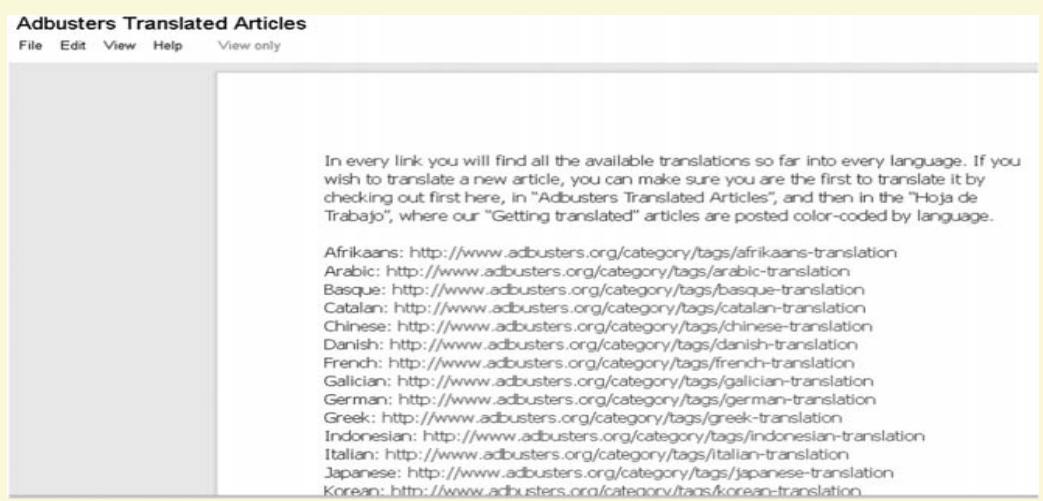

Figura 2. Traduções dos artigos do Adbusters pelo Brigada de Tradutores.

\footnotetext{
$14<\mathrm{http}: / /$ translatorbrigades.wordpress.com/about/ > . (Acesso: 9 mar.2012).

$15<$ http://translatorbrigades.wordpress.com/about/ > . (Acesso: 9 mar. 2012).

16 < https://docs.google.com/document/d/1zDEzDVs1DomZ3LA5-14CJgrqmsA6hGQ NaWwHIWA2ek/ edit?hl 1/4 en_US\&amp;pli1 $1 / 41>$. (Acesso: 9 mar. 2012).
} 
O site exibe apenas quatro seções de línguas - grego, português, espanhol e turco - com conteúdo em cada uma, mas sem conteúdo em inglês, exceto na página "Sobre Nós" (Figura 3). Como ficará claro na análise a seguir, a observação da relação entre diferentes línguas e da(s) direção(ções) da tradução é um elemento importante da política prefigurativa de muitos, mas não de todos os grupos em análise, e sinaliza o nível de conscientização de cada grupo sobre o projeto político mais amplo de movimentos globais contemporâneos.

A forma de afiliação ao grupo Brigada de Tradutores não é clara: não há nomes nem indicação de pessoas responsáveis pelo projeto. Por outro lado, o Tlaxcala fornece informação detalhada sobre as pessoas que participam do projeto. Em 2009, eram 74 membros e eram oferecidas traduções em 13 línguas, sem prioridade para nenhuma como língua de partida ou de chegada. Hoje, ainda são oferecidas traduções de e para 13 línguas, mas é difícil determinar exatamente quantos tradutores se consideram "membros" do grupo. Em 2009, a lista de tradutores aparecia na seção intitulada "Who We Are" (quem somos); o site atual, no entanto, lista os tradutores na "Library of Translators" (biblioteca dostradutores), uma seção que faz parte de uma seção maior que abrange "Library of Authors" (Biblioteca de Autores), "Library of Translators" (Biblioteca de Tradutores) e "Library of Editors" (Biblioteca de Editores). A primeira classificação na seção "Who We Are" claramente sinaliza que qualquer pessoa listada se considera parte do grupo; além disso, essa categoria sugere ainda uma identidade estável que está fora de sintonia com a cultura contemporânea de movimentos políticos. Em contrapartida, a classificação atual indica uma associação muito mais flexível de contribuidores do projeto. A mudança de designação e a flexibilidade da atual estrutura sugerem um processo de amadurecimento político que aproxima o grupo das formas de ação coletiva descritas por Melucci (1996) e do caráter de movimentos autônomos discutido por Flesher Fominaya (2007). Além disso, a atual "Biblioteca de Tradutores", com 40 páginas na web, não apresenta informações de todos os nomes da lista, mas informa tanto o nome das pessoas 
como também de outros grupos e associações, inclusive o Fórum Social Mundial, cujo conteúdo é exibido pelo Tlaxcala ocasionalmente (Figura 4), o que sugere identificação com o projeto político de fóruns coletivos, apesar de o Tlaxcala não oferecer tradutores e intérpretes voluntários para o Fórum Social Mundial ou comunidades semelhantes.

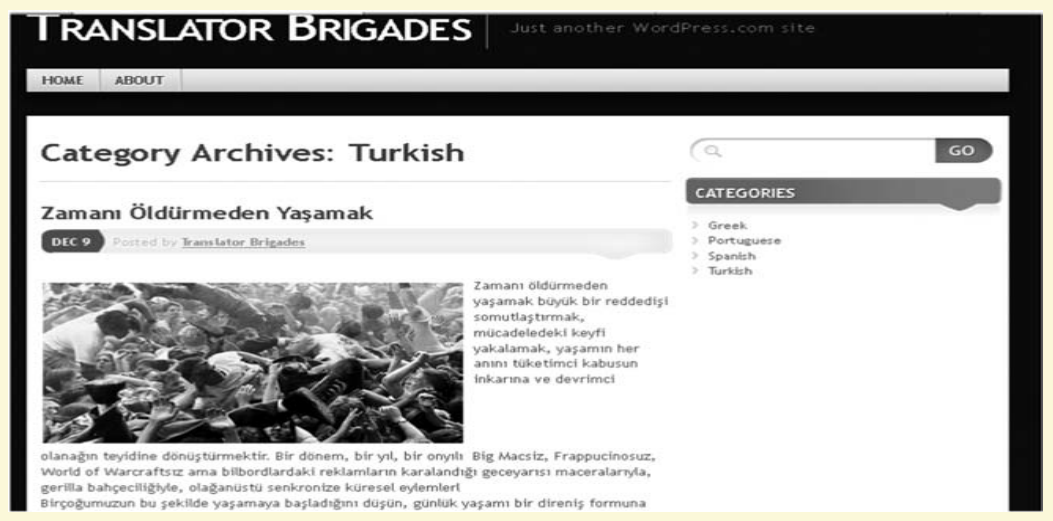

Figura 3. Site do grupo Brigada de Tradutores e o conjunto de línguas.

Até mesmo os indivíduos listados não são necessariamente colaboradores do site.Por exemplo, WaelAly (Abouleil) não é descrito como um colaborador, mas como alguém que o Tlaxcala "adotou como um membro honorário, em solidariedade com ele e todos os egípcios que continuam a revolução iniciada em 25 de janeiro de 2011, apesar de todos os obstáculos e da opressão contínua"; não existe nenhuma indicação de que ele já tenha fornecido material para o site. No entanto, a seção lista inúmeros tradutores que parecem ser colaboradores regulares, pelo menos era a informação em 2009, com biografias detalhadas em várias línguas. Alguns, como Supriyo Chatterjee, são descritos explicitamente (na terceira pessoa) como membros do Tlaxcala: 
Agora na casa dos cinquenta anos, Supriyo Chatterjee divide seu tempo entre a Índia e a Inglaterra e dedica-se a atividades para e com organizações populares na Índia e a traduções em espanhol, inglês e bengalês. Ele é membro do Tlaxcala. ${ }^{17}$

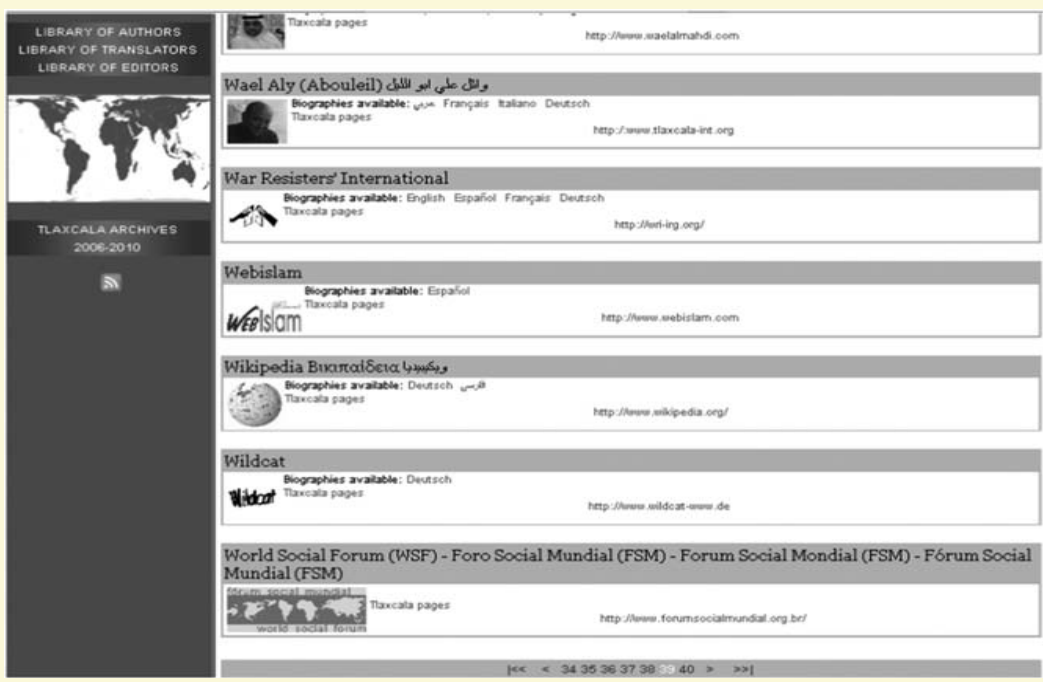

Figura 4. Extraído da "Biblioteca de Tradutores" do Tlaxcala, que exibe o FSM como um membro.

Isso reforça a mensagem de que nem todos os indivíduos da lista são ou se consideram membros do grupo e de que o próprio grupo não é uma estrutura estável com limites que o separam claramente de indivíduos e de grupos que estão de fora. Entretanto, apesar de sua estrutura flexível, o Tlaxcala - diferente do Babels, outro grupo analisado abaixo - ainda não se descreve como uma rede completamente autônoma e "biodegradável” que se "dissolve

$17<$ http://www.tlaxcala-int.org/biographie.asp?ref_aut $1 / 4$ 87\&amp;lg_pp 1/4en >. (Acesso: 9 mar. 2012). 
e se regenera em novas formas de organização e ação" (FLESHER FOMINAYA, 2007, p. 339).

Se considerarmos os indivíduos e grupos que o Tlaxcala lista em seu site como associados eventuais ou membros comprometidos que subscrevem ao manifesto do grupo, a lista que aparece na "Biblioteca de Tradutores" tem uma composição extremamente variada. Esta inclui indivíduos de várias partes do mundo, de diversas origens étnicas, falantes de diferentes línguas, com biografias bastante variadas. A diversidade de pessoas reunidas nesse projeto apresentou-se ainda mais evidente em 2009, quando os "membros" apareciam em "Who We Are" e suas biografias eram redigidas com um estilo mais pessoal, sem referência em terceira pessoa.Os membros então se descreviam com denominações bem diversas - como brasileiro, mexicano, feminista, ativista, iraniano, bioquímico, turco, internacionalista, italiano, francês, palestino-americano, muçulmano, sociólogo, humano, mãe, jornalista, professor, filologista - e quase sempre como "tradutor" (Figura 5). Essa diversidade na maneira de se identificar, ou não se identificar, dava ao grupo um caráter particularmente espontâneo e novo.Ressalte-se que o Tlaxcala é o único grupo que continua a fornecer biografias detalhadas de seus membros e colaboradores, com inclusão de fotografias; essas expressões concretas de múltiplas identidades reforça a ênfase do Fórum Social Mundial na "unidade na diversidade" em termos individuais e pessoais (em vez do movimento) e está alinhada com a ideia do sujeito autônomo "multifacetado, com múltiplas identidades que se sobrepõem" (Flesher Fominaya, 2007, p. 340). 


\begin{tabular}{|l|l|}
\hline Atenea ACEVEDO. Mexican. Internationalist, Translator and interpreter. Feminist, Activist. \\
\hline Aftp
\end{tabular}

Figura 5. Seção "Who We Are” do Tlaxcala, 2009.

Todos os grupos dessa primeira categoria se concentram em produzir e circular traduções escritas de textos que eles mesmos selecionaram. Como a rede de fansubbers analisada por Pérez-Gonzáles ${ }^{18}$, eles "agem como clientes autonomeados que escolhem o que deve ser legendado para a realização da tradução" (2007, p. 71) - ou, nesse caso, o que deve ser traduzido, postado no website e circulado por meio de lista de e-mails e outros meios ${ }^{19}$. De forma semelhante, enquanto um grupo como o Adbusters, com o qual o Brigada de Tradutores se identifica explicitamente, empenha-se em disseminar informação sobre a desagradável prática de negócios de empresas como a Nike, a fim de "desmerecer a marca" (Carty, 2002, p. 141), poderíamos dizer que os grupos analisados aqui usam suas habilidades linguísticas para disseminar contranarrativas que podem “desmerecer" decisões importantes a respeito de uma

\footnotetext{
${ }^{18}$ Fansubbers são fãs/legendadores amadores de filmes e programas de TV estrangeiros.

${ }^{19}$ Até o momento, nenhum dos grupos discutidos aqui se aventurou a legendar, embora muito do material ativista que circula na internet agora apareça em formato de videoclipes.
} 
série de questões, incluindo o cerco de Gaza, a pobreza contínua na África e o tráfico de drogas na América Latina. Cada tradução produzida funciona como um episódio em uma narrativa em construção; esta, por sua vez, um episódio de uma narrativa ainda maior.

No caso do grupo Tlaxcala, o maior e mais complexo, cada conjunto de narrativas, tal como indicado em traduções individuais, é classificado dentro de um título específico: África, AbyaYala, Ásia e Oceania, Palestina, Umma, Europa, EUA e Canadá. Em conjunto, as traduções individuais em cada seção produzem um tipo de narrativa ou conjunto de narrativas relacionadas à região em questão, por exemplo as narrativas sobre as causas da pobreza e dos conflitos na África.Essa narrativa é elaborada a partir da seleção do que será traduzido e incluído em cada seção e a partir do modo como essa seção é enquadrada, sempre dentro de uma narrativa maior de um ataque imperial sobre culturas mais fracas, narrativa essa que se desdobra ao longo de um extenso período de tempo, segue um enredo familiar, se projeta sobre um futuro no qual os membros do grupo e outros ativistas são convidados a participar e apresenta diversos tipos de personagens abstratos como também protagonistas mais específicos.Por exemplo, AbyaYala, o título de uma das seções, significa:

Terra viva: o nome indígena da América Latina

No espírito de José Martí e dos povos nativos, ABYA YALA é um conjunto de tudo que está relacionado com a Nossa América, essa terra viva que vai do Rio Bravo à Terra do Fogo, inclusive as ilhas caribenhas e as primeiras nações da América do Norte.

Umma significa:

Esperanças comuns

Os povos, grupos e territórios marcados pela civilização islâmica. Uma comunidade de cren- 
ças, valores, debates e esperanças, que agrupa um quarto da humanidade.

Como os outros grupos em discussão, os tradutores do Tlaxcala se empenham ativamente em renarrar o mundo de uma posição e localidade específicas, usando a tradução como um meio de reconfigurar as relações entre protagonistas e eventos em uma história que tem vários desdobramentos do mundo em que eles vivem.

\section{Tipo 2: Interpretação para Fóruns Coletivos e para a Comunidade}

O grupo ECOS e o Babels são exemplos de um segundo tipo de grupo de ativistas que trabalha especialmente em fóruns ou na comunidade. ECOS (Traductores e Intérpretes por la Solidaridad) ${ }^{20}$ foi criado em Granada em 1998 por professores e estudantes de tradução e interpretação da Universidade de Granada (BALSALOBRE et al. 2010). O grupo ECOS “dedica-se a duas questões: facilitar a comunicação, através de barreiras linguísticas, dos indivíduos e grupos excluídos do mercado institucional e privado; e "ecoar" (dar eco) ou dar visibilidade às situações no nosso mundo contemporâneo que são silenciadas porque não são prioridade para os que controlam a mídia dominante" (BALSALOBRE et al. 2010, p. 9).

Diferente dos grupos discutidos acima, o ECOS coloca tradutores e intérpretes voluntários à disposição de vários setores da sociedade civil. Além disso, os membros da associação também organizam palestras locais, em Granada, para o público (algumas vezes com palestrantes internacionais) com o intuito de promover a conscientização sobre questões sociais e políticas contemporâneas, incluindo comércio justo e a situação no Iraque e no Oriente Médio. Embora sua atuação seja local desde a sua criação, a partir do segundo Fórum Social Europeu (FSE) em 2003, o ECOS tem colaborado com outro grupo ativista, o Babels, em alguns eventos

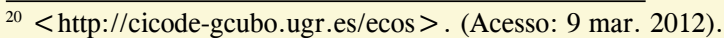


internacionais, especialmente o Fórum Social (BALSALOBRE et al. 2010, p.9). O seu website inclui uma seção completa intitulada ECOS-Babels, para dar ênfase a essa relação. (Figura 6). Esse padrão de colaboração representa uma área em que grupos ativistas no mundo da tradução e interpretação atuam como outros movimentos de ação coletiva, não apenas em termos de objetivos, mas também de ações.

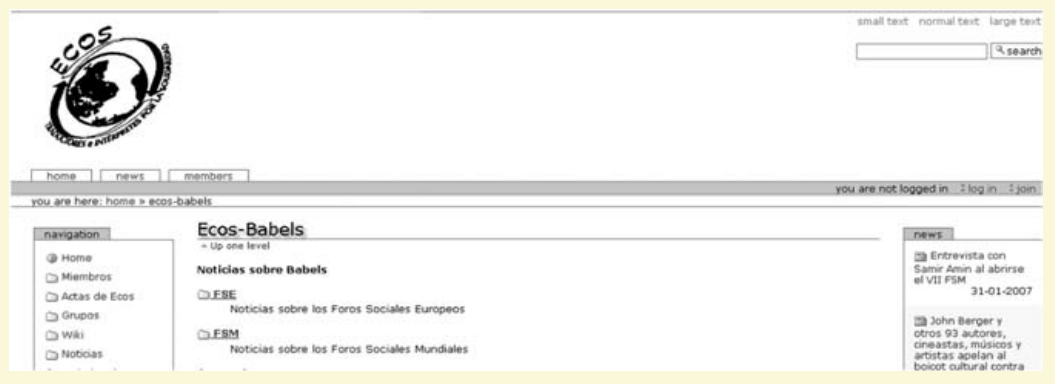

Figura 6. Seção ECOS-Babels no site do ECOS.

O Babels é de longe a maior e mais conhecida comunidade de ativistas em discussão.Ele foi criado em setembro de 2002 por um grupo de ativistas ligados ao ramo francês da ATTAC (Associação pela Tributação das Transações Financeiras para ajuda aos Cidadãos), para atender às necessidades de tradução e interpretação do FSE em Florença. O estatuto do Babels descreve explicitamente o grupo como um "um ator do debate 'anticapitalista'" e demonstra seu compromisso com o debate e a experimentação como formas de engajamento político:

O grupo Babels é:

- Uma rede de intérpretes e tradutores.

- Um ator do debate 'anticapitalista'.

- Um laboratório para a evolução das línguas, das palavras e de suas diferenças terminológicas; propostas de tradução de termos técnicos, ou de conceitos, haja vista a sua herança linguística. 
- Uma forma de propor, no âmbito de uma organização, eventos internacionais nos quais o grupo Babels poderia participar: e.g. escolha das línguas, organização de seminários, de conferências ou workshops em torno do tema das línguas e da diversidade linguística.

- Um espaço de encontro entre intérpretes e organizações que se reúnem nos diferentes eventos: reuniões técnicas entre palestrantes e intérpretes e assistência na comunicação oral ${ }^{21}$.

Uma versão anterior do website apresentava uma explicação para a forma no plural de "Babels" como nome do grupo: foi idealizado para "salientar a característica supranacional da associação". O grupo Babels, como o Tlaxcala e o Brigada de Tradutores, e diferentemente do ECOS, dos Tradutores pela Paz e do TUP, foi concebido desde o começo como uma rede transnacional de ativistas.

A estreia do Babels foi em Florença em 2002 com 350 tradutores e intérpretes voluntários trabalhando sem um orçamento definido e sem instalações básicas, como computadores e telefones (HODKINSON; BOÉRI, 2005).Entretanto, o sucesso e a dedicação do grupo convenceram os organizadores do FSE seguinte a oferecer melhores instalações e uma quantia relativamente alta no valor de 200 mil libras para o grupo se preparar para o Fórum de Paris.O Fórum de Paris, realizado em 2003, contou, para a mediação, com mais de mil "Babelitos" escolhidos a partir de um grupo de voluntários quatro vezes maior. No FSE de Londres, em outubro de 2004, o banco de dados do Babels tinha mais de sete mil voluntários que trabalharam com 63 línguas (BOÉRI; HODKINSON, 2005). Em 2005, o número de voluntários registrados no Babels tinha aumentado para nove mil. Qualquer que seja a referência, este é um número impressionante de tradutores e intérpretes, ou de pessoas com as habilidades linguísticas necessárias, envolvendo-se ativamente e dedicando-se à tarefa de vislumbrar um mundo diferente, no qual

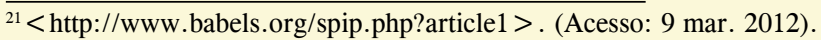


qualquer pessoa possa ter voz e contribuir para o debate, falando ou não uma língua colonizadora como inglês e francês.

O grupo Babels, como o ECOS e o Brigada de Tradutores, nunca divulgou uma lista de membros. Os membros que postam mensagens e relatórios sobre eventos assinam as mensagens e relatórios com seus nomes, frequentemente apenas o primeiro nome, mas não há, no entanto, uma lista de indivíduos no site. Isso ocorre, possivelmente, por causa da dimensão e fluidez do grupo. A ausência de uma lista também alinha-se com a posição política geral do grupo e seu envolvimento na cultura do Fórum Social Mundial: o Babels tem como princípio colocar em primeiro plano o caráter coletivo do projeto e minimizar o papel de qualquer indivíduo dentro do grupo.Retomarei essa questão quando discutir sobre a resistência a padrões de representação doBabels. A resistência à representação e hierarquia é característica da maioria dos outros grupos em discussão; entretanto, ao ser "orgânico" 22 ao Fórum Social Mundial, o Babels reflete explicita e extensivamente sobre questões como representação, participação, deliberação, processo, etc. de forma contínua (ver BOÉRI (2009) para uma análise detalhada dos debates sobre esses princípios entre os membros do Babels).

\section{Posicionamento e dinâmica de grupos ativistas de tradutores}

Apesar das particularidades, tais como observadas no caso do Babels, do ECOS, do Brigada de Tradutores e do Tlaxcala, os grupos ativistas de tradutores são estruturados, operam e narram a si mesmos de forma semelhante a outros movimentos de ação coletiva. Eles não têm como um de seus objetivos específicos tomar o poder ou conseguir um conjunto de demandas políticas dentro de um determinado período de tempo, mas efetuar uma mudança

${ }^{22}$ A forma de organização do Babels para o Fórum Social Mundial é tema de debate contínuo dentro da rede (BOÉRI, 2009). 
gradual de consciência que possa ter efeitos duradouros - de forma global, não local. Como os membros do ECOS enfatizam, eles se propuseram a alcançar "uma transformação profunda nas [...] estruturas injustas, em vez de promover meras reformas, que, de fato, só dão mais legitimidade à ordem atual" (BALSALOBRE et al., 2010, p. 9). Isso está de acordo com a mudança geral de padrões de resistência; a título de exemplo Melucci (1996), entre outros, explica que nossas sociedades contemporâneas "não têm centros" e agora é muito mais difícil identificar e tomar os instrumentos centrais de poder. Os movimentos contemporâneos percebem nesse contexto que é "tão importante conscientizar quanto comandar ações” (Notas de NOWHERE, 2003, p. 65), que a informação tornou-se um recurso crucial e que a ação coletiva deve, portanto, concentrar-se em mudar a consciência e o discurso público, em vez de efetuar mudança por força material. Neste contexto, a tradução e a interpretação tornam-se muito mais importantes, de fato fundamentais para satisfazer os objetivos dos movimentos políticos contemporâneos. Elas tornam-se um espaço privilegiado de ação política por direito próprio.

Melluci (1996, p. 308) identifica a "globalidade" como uma das características da mobilização nos movimentos contemporâneos. "Reconhecer a globalidade", ele explica, significa "levantar questões que envolvem não apenas grupos sociais específicos, mas, de forma mais geral, o sistema" (grifo no original). Na maior parte das vezes, os grupos discutidos aqui deixaram de defender questões isoladas/individualizadas e se voltaram para a globalidade. Seus objetivos e práxis são essencialmente de alcance global, mesmo quando eles abrem espaço para lutas locais específicas, como no caso do Tlaxcala. As lutas locais são usadas como modelos, elementos narrativos a serem integrados a uma narrativa maior que engloba o mundo inteiro e o sistema, em vez de apresentar um foco particular para o ativismo em grupo. Nem todos esses grupos começaram com uma pauta diversificada e global que questionava a ordem mundial dominante, porém mesmo aqueles que começaram em um espaço físico específico - Espanha, no caso do ECOS, Itá- 
lia, no caso do Tradutores Pela Paz, Japão, no caso do TUP - tendem a ampliar ou "globalizar" suas pautas em graus variados com o tempo, não apenas em termos de colaboração com outros grupos em âmbito internacional, mas também de expansão de suas responsabilidades além do conjunto restrito de questões tratadas inicialmente. À medida que evoluem, eles parecem trabalhar de modo mais consciente para evitar uma potencial categorização, como de grupos monotemáticos, o que reflete uma tendência maior em direção ao ativismo de múltiplas questões, tal como documentado em Tarrow (2006) e reconhecido por della Porta e Mosca (2010, pp. $66,76)$ como uma das contribuições de fóruns sociais locais para o movimento global de justiça. Por exemplo, uma versão anterior do website do ECOS destacava questões referentes à Palestina (Figura 7), mas a versão mais recente do site minimiza a importância de questões específicas em favor de uma pauta mais ampla.Isso sugere que grupos ativistas no mundo da tradução e da interpretação estão se alinhando mais com os movimentos globais de ação coletiva, com uma mudança constante no sentido de comprometer-se com uma variedade de temas que ultrapassam questões regionais e questionam a própria ordem política e social.

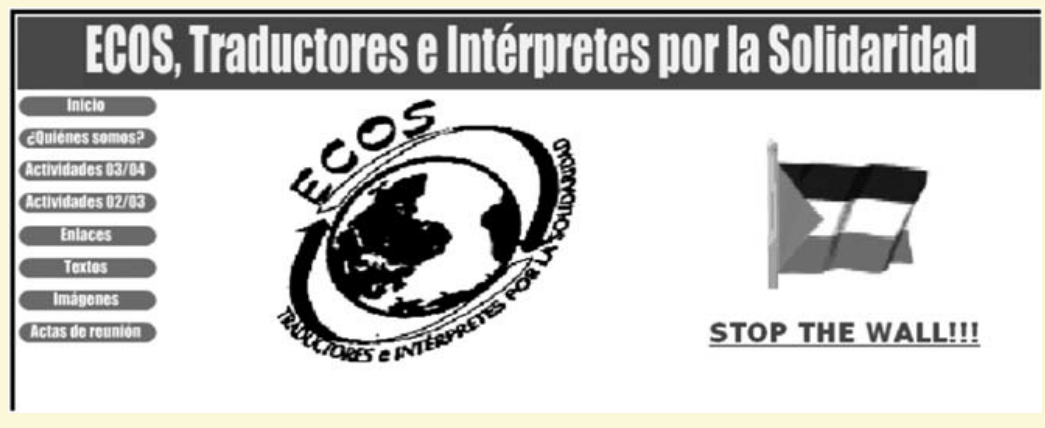

Figura 7. Destaque à questão da Palestina em versão anterior do site do ECOS.

Além de ter uma atuação cada vez mais global, esses grupos também são transnacionais e transprofissionais em sua composi- 
ção. Os indivíduos que constituem esses grupos traduzem e interpretam - essa é a contribuição deles para a luta. Eles também vêm de contextos muito diferentes; alguns são tradutores e intérpretes qualificados, incluindo estudantes e professores de tradução; outros são tradutores e/ou intérpretes profissionais especializados com poucos ou muitos anos de experiência. E alguns não são nenhum dos dois; podem ser sociólogos, estudantes de literatura, biólogos ou jornalistas. Podemos pensar neles, em geral, como tradutores e intérpretes "amadores", no sentido empregado por Edward Said"23: não significa que eles não sejam qualificados, mas como grupo ou indivíduos, eles não são afiliados à profissão ou a instituições que representam tradutores e intérpretes, como a $\mathrm{AIIC}^{24}$, a International Association of Conference Interpreters.

Não apenas esses grupos evitam manter relações formais com associações profissionais, mas alguns, como o Babels e o ECOS, são também considerados, por muitos profissionais que pensam a tradução puramente como um serviço e não um ato político em si, prejudiciais ao status da profissão em razão de tirar o trabalho dos profissionais e de oferecer interpretações de baixa qualidade que denigrem a imagem da profissão (NAUMANN, 2006; BOÉRI, 2008). Esses grupos poderiam ainda potencialmente prejudicar a confiança do cliente ao enfraquecer os princípios fundamentais de neutralidade e imparcialidade que definem a tradução no contexto da economia de serviços. O Babels, por exemplo, já foi acusado de atrapalhar o funcionamento do mercado ${ }^{25}$. Criticou-se que uma interpretação gratuita no Fórum Social permitiria que os organizadores deixassem de contratar e pagar pelo serviço de intérpretes profissionais. Argumentou-se ainda que os organizadores estariam dispostos a pagar por outros serviços e, portanto, também deveriam estar dispostos a pagar pela interpretação.

${ }^{23}$ Cf. a discussão de Atton sobre o papel de "jornalistas amadores" na história da mídia de movimentos sociais (2003, p. 10).

${ }^{24}$ AIIC é a sigla da Associação Internacional de Intérpretes de Conferência. Ver: < http:// www.aiic.net/ >. (Acesso: 11 ago. 2011).

${ }^{25}$ Para uma maior discussão crítica sobre algumas das críticas levantadas contra o Babels em particular, ver Boéri (2008). 
Portanto, diferente de outros grupos de ativistas, o fato de eles oferecerem um serviço normalmente fornecido por profissionais representados por associações e se definirem tradutores em nome do grupo e nas suas próprias narrativas, como discutido anteriormente, significa que em alguns aspectos os grupos aqui discutidos se encontram entre o mundo do ativismo e as políticas de competição profissional e o ethos da economia de serviços. A análise de Boéri (2009) a respeito de discussões entre membros do Babels ao longo de um período para estabelecer como a narrativa pública do grupo evoluiu mostra que elaborar uma narrativa aparentemente estável e simplificada do grupo implicou uma negociação considerável entre muitos "Babelitos". Essa negociação revelou muitas vezes sensibilidade ao posicionamento do Babels vis-à-vis à profissão, apesar do caráter deliberadamente "amador" do grupo, como apresentado abaixo (BOÉRI, 2009, p. 79):

Sou categoricamente contra qualquer intervenção do Babels além do FSE e do FSM... Afinal, existe um grande risco de competição desleal com intérpretes profissionais. Quando todas as associações ficarem cientes de que existe uma grande quantidade de intérpretes voluntários, elas não estarão dispostas apagar por interpretação, mesmo se tiverem condições para isso. É muito fácil refutar essa hipótese com o argumento de que intérpretes profissionais são levados por interesses financeiros e de que oferecer interpretação gratuita é algo gratificante. Não é o papel dos grupos, que têm supostamente consciência dos problemas sociais, prejudicar o mercado. (Sarah, Fórum do Babels, 28 de março de 2004; traduzido do francês por Julie Boéri).

De forma semelhante, o ECOS se viu obrigado a "explicar" e a justificar suas atividades para a comunidade de tradutores e intérpretes profissionais, que se sentiu ameaçada por suas atividades (MANUEL JEREZ et al. n.d.): 
Na associação ECOS, Tradutores e Intérpretes pela Solidariedade, nós realizamos trabalho voluntário de tradução e interpretação para ONGs, fóruns sociais e outras organizações sem fins lucrativos em consonância com a filosofia de nossa organização. De forma alguma, pensamos exercer a função de um profissional para um serviço que deveria ser fornecido por profissionais contratados. ${ }^{26}$

Posicionar-se como "amadores" não afiliados não torna esses grupos imunes à pressão de profissionais que oferecem habilidades semelhantes em troca de remuneração. Mas é uma escolha que eles continuam a fazer.

Como outros movimentos contemporâneos, os grupos aqui discutidos também rejeitam padrões de representação e todas as formas de hierarquia, e não se consideram grupos estáticos com estruturas e objetivos definidos, mas redes flexíveis de pessoas de opiniões semelhantes e projetos experimentais que estão sempre se renovando. A rejeição do Brigada de Tradutores à hierarquia e à representação fica evidente em sua declaração sobre tomada de decisão e também demonstra outro aspecto da prefiguração que caracteriza esses grupos, mais especificamente a experimentação de formas de implementar a democracia em âmbito global "dentro de seus próprios processos organizacionais” (MAECKELBERGH, 2011, p.3):

Tomada de decisão

Quem decide o que o grupo traduz? Cada pessoa no grupo decide o que ele ou ela gostaria de traduzir. Enquanto algumas tarefas são delegadas e as pessoas são incentivadas a assumir papéis de facilitadores do grupo, não há líderes, hierarquia ou orientação centralizada. ${ }^{27}$

Rejeição à hierarquia acarreta modelos específicos de funcionamento; "um movimento sem nenhum líder organiza-se horizontal-

\footnotetext{
${ }^{26}<$ http://cicode-gcubo.ugr.es/ecos/artecos/articuloingles > . (Acesso: $11 \mathrm{mar} .2012$ ).

$27<$ http://translatorbrigades.org/?q1/4about $>$. (Acesso: 9 mar. 2012).
} 
mente, por meio de redes" (Notas de NOWHERE, 2003, p. 64).O modo de operação do Babels reflete isso.O grupo adota explicitamente uma "lógica de trabalho em rede" ao invés de uma "lógica de comando” (Juris, 2005), como exposto na página 'Sobre Nós':

\begin{abstract}
Como o Babels trabalha?
Babels é uma rede horizontal de trabalho, sem hierarquia e nenhuma estrutura permanente de qualquer tipo, onde todos são voluntários e trabalham em atividades que são livremente escolhidas. Alguns fazem interpretação em cabines. Outros são voluntários dos projetos iniciados pelo Babels ou que têm a sua contribuição. Alguns elaboram glossários para internacionalizar, ampliar e moldar a língua com as causas que nos interessam. Todos contribuem para o debate político e para um posicionamento mais ativista com relação à língua e à organização horizontal. ${ }^{28}$
\end{abstract}

De todos os grupos discutidos aqui, talvez o Babels seja o que mais faz reflexão e que está mais alerta ao seu posicionamento dentro do cenário dos movimentos contemporâneos de ação coletiva em constante mudança. Seus membros criaram diversos espaços no website, incluindo o Fórum Babels, o Wiki, o Chat e o baBeLOG, onde eles debatem de forma contínua questões como representação versus participação, evento versus processo, deliberação versus luta e modos de operação horizontal versus vertical.Para Flesher Fominaya (2007), trata-se de uma "rede biodegradável” e de um "caso clássico" de movimentos contemporâneos de ação coletiva como descrito por Melucci (1996, p. 115):

Acima de tudo, $[\ldots]$ observa-se a estrutura segmentada, reticular e multifacetada dos "movimentos". É uma estrutura oculta, ou melhor, uma estrutura latente; células individuais operam sozinhas de forma independente do resto do movi-

$28<$ http://www.babels.org/spip.php?article272>. (Acesso: 11 ago. 2011). 
mento, embora elas continuem ligadas por meio da circulação de informação e das pessoas. Essas ligações tornam-se explícitas apenas durante os breves períodos de mobilização coletiva sobre questões que fazem com que a rede latente fique aparente e permitem à rede desaparecer novamente no cotidiano.

Todas as atividades do Babels são organizadas em torno de projetos interligados de forma flexível, que são organizados temporariamente para eventos específicos. O Protocolo do Babels resume o processo da seguinte maneira:

Resumo do Protocolo:

1. Criação de um novo projeto.Vide Protocolo de Comunicação para detalhes.

2. O Babels-Tech cria uma nova lista e gestão para um projeto.O projeto deve ter prazos (se aplicável), para que saibamos quando não é mais necessário recrutar novos voluntários. Por exemplo, se um fórum termina em 31 de março, o projeto deve terminar em 31 de março, e a lista será retirada da página de registro nessa data, o que não significa que a lista é deletada.O projeto deve também ser claramente descrito.

3. A gestão envia uma mensagem a voluntários usando alista ("InfoBabels") para explicar que um novo projeto foi criado e que voluntários devem subscrever-se ao novo projeto caso estejam interessados.

4. O projeto é organizado pela gestão juntamente com a lista referente ao projeto.Essa lista é usada para contatar os voluntários que escolheram se subscrever à nova lista/projeto.A gestão do projeto pode analisar os arquivos de voluntários de forma detalhada.

5. Uma vez concluído o projeto, a lista é removida da página de registro, e a gestão relativa ao projeto é retirada pouco depois disso. Se o projeto tomar uma nova forma, um novo projeto deverá ser criado, para permitir que outras pessoas 
também se apresentem como voluntários - e o protocolo é iniciado novamente. ${ }^{29}$

Esta forma "cíclica" de mobilização, como Melucci explica, pode servir para fortalecer ao invés de dispersar as redes de solidariedade e, principalmente, "proteger as várias células do efeito de forças centrífugas que ameaçam a integridade do movimento" (1996, p. 116). Uma rede sem líder(es) para representá-la e sem uma estrutura permanente e estável é mais difícil de cooptar membros do que uma que seja difusa e que dependa de formas de mobilização transitórias e fluidas. Mas essa fluidez e abertura são inquietantes e tendem a ser vistas com desconfiança por uma comunidade profissional que procura ininterruptamente crescer ao invés de enfraquecer sua própria institucionalização para promover e salvaguardar seus interesses. Membros de uma rede flexível e aberta que referem a si mesmos como tradutores e intérpretes não podem ser responsabilizados por seus pares, e o impacto de seu comportamento em relação à profissão não pode ser controlado por instituições, como a AIIC, que investem na ideia de que eles "representam" a profissão.

Outra fonte de tensão desses grupos, no que se refere ao relacionamento deles com outros movimentos ativistas, é o fato de que o tipo de solidariedade que eles oferecem consiste em uma forma de serviço voluntário profissional. Os objetivos e o funcionamento desses grupos compartilham certas características com um tipo específico de ação coletiva que Melucci chama de "ação altruísta" (1996, pp. 166 - 170) e define como "uma forma de altruísmo social coletivo, organizado e propositado" (p.168). Como movimentos sociais e políticos contemporâneos, ele explica, a ação altruísta é "direcionada contra os processos pelos quais os códigos culturais dominantes são formados [...] Por sua simples existência, tal ação desafia o poder, perturba sua lógica e constrói significados alternativos. Essa ação indica que o encontro com o "outro"

${ }_{29}<$ http://www.babels.org/spip.php?article30>. (Acesso: 12 ago. 2011). 
não é reduzível à lógica instrumental" (MELUCCI, 1996, p. 169). O tipo de ação coletiva realizada pelos grupos ativistas discutidos aqui compartilha diversas características com as formas de ação altruísta nos termos de Melucci.

Em primeiro lugar, a ação em que esses grupos estão engajados é altruísta porque é voluntária: "Um ator voluntário se junta a uma forma de solidariedade coletiva por conta própria e pertence a uma rede de relações em virtude de uma escolha pessoal" (MELUCCI, 1996, p. 167). Em outras palavras, esses grupos não funcionam como sindicatos e não há exigências sociais, implícita ou explicitamente, que leva os indivíduos a oferecer seus serviços como tradutores ou intérpretes. Em segundo, no que concerne aos objetivos, a ação altruísta é "especificamente destinada a produzir benefícios ou vantagens para pessoas que não sejam os voluntários, e, portanto, assume a forma de um serviço prestado ou bem distribuído para outros" (MELUCCI, 1996, p. 167). Isso é precisamente o que os grupos ativistas de tradutores e intérpretes fazem. Eles fornecem um serviço para outros, um serviço que beneficia os outros, e não eles mesmos. E ainda, como Melucci explica, o que mais distingue altruísmo de outros tipos de ações é que os "benefícios econômicos não constituem a base do relacionamento entre os envolvidos, nem entre eles e os beneficiados da ação realizada" (1996, p. 167). Embora a ação seja gratuita, ela não envolve ganhar ou economizar dinheiro para o grupo de voluntários ou a comunidade para a qual eles se voluntariam. Isso é um ponto de discórdia contínua na relação do Babels com o Fórum Social, como documentado em detalhe em Boéri (2009). Embora o grupo forneça interpretação gratuita, o que faz com que o Fórum reduza os custos de contratar um profissional, oBabels afirma veementemente que ele não se voluntaria para o Fórum economizar, mas, como a seção "Sobre Nós" explica, "para dar voz aos povos com línguas e costumes diferentes [...] para lutar pelo direito de todos, incluindo aqueles que não falam a língua dominante, para contribuir a uma causa comum [... e] para permitir que todos se expressem na língua de sua escolha”. Em outras palavras, o Babels vê seu trabalho como uma ação política 
direta, ao criar um espaço para múltiplas vozes, ao invés de fazer com que o Fórum Social economize com o custo da interpretação. O Fórum já explicou diversas vezes que não considera o Babels um prestador de serviço de baixo custo, mas um membro ativo e coorganizador do Fórum (LAMPROPOULOU, 2010, p. 29), com um papel importante na formação da concepção do FSM.

Como "amadores" e como "voluntários" engajados em ação altruísta, os grupos discutidos ocupam um espaço ambivalente entre o ativismo e a economia de serviço. Eles são obrigados a lidar com as tentativas dos profissionais de narrá-los como uma ameaça à profissão e com a tendência de outros ativistas de tratá-los como prestadores de serviço de baixo custo e não também como ativistas no campo político.

\title{
Prefiguração: invertendo a ordem simbólica
}

Melucci (1996) discute as maneiras pelas quais os movimentos contemporâneos tentam "inverter a ordem simbólica" para enfraquecer as bases do poder em sociedades cada vez mais complexas. Com relação a isso, o autor argumenta (1996, p. 357):

\begin{abstract}
Movimentos contemporâneos empenham-se em retomar a capacidade de nomear por meio da elaboração de códigos e línguas projetadas para definir a realidade, no sentido de tanto constitui-la simbolicamente como reconquistá-la, escapando assim das formas predominantes de representação.
\end{abstract}

Grupos ativistas como oBabels e o Tlaxcala engajam-se nesse processo de renomear e renarrar o mundo usando uma variedade de recursos, especialmente aqueles fornecidos pela nova mídia e tecnologias. Como Carty e Onyett (2006, p. 230) argumentam, "novas formas de tecnologia estão redefinindo a luta política ao fornecer os recursos e os meios necessários para uma resistência 
organizada e coesa". Alguns desses recursos são simbólicos e permitem que os grupos discutidos aqui criem espaços onde tradução e interpretação possam funcionar como ferramentas emancipatórias e de resistência. Esses também são espaços onde os grupos podem praticar prefiguração política de uma maneira que não seja apenas instrumental na articulação de sua concepção, mas também vital para manter e proteger o grupo como um meio de ação coletiva. Como Melucci explica (1996, p. 328 - 329):

\begin{abstract}
Os movimentos contemporâneos mantêm um grau de separação dos códigos culturais dominantes por meio da constituição e operação de formas organizacionais que prefiguram os objetivos almejados e por meio de suas atividades concernentes aos problemas sociais. [...] Quanto maior a ênfase no desafio e maior o destaque dessa prefiguração, menor será o risco de as formas organizacionais serem assimiladas ou cooptadas.
\end{abstract}

Em outras palavras, a prefiguração é estratégica em mais de um sentido (MAECKELBERGH, 2011); ela não apenas provoca mudanças ao adotar os princípios defendidos aqui e agora, mas também protege um grupo como oBabels de ser cooptado.

As novas tecnologias permitem grupos como o Babels e o Tlaxcala engajarem-se em políticas prefigurativas de maneira que são específicas da tradução: por meio de layout, cor, links, listas em cascata e uma variedade de outras características que podem ser manipuladas para reconfigurar a relação entre as línguas. Tanto o Babels quanto o Tlaxcala, e em menor escala o Brigada de Tradutores, usam tais recursos para enfraquecer deliberadamente o poder do inglês, como parte de seu compromisso com a diversidade linguística. Por exemplo, a página inicial do Babels exibe no topo um banner altamente colorido, com equivalentes de "Welcome" em diversas línguas: árabe, hebraico, grego, tailandês, espanhol, italiano e turco, entre muitas 
outras. Chama a atenção que o inglês, a língua franca do mundo, esteja ausente (Figura 8).

Uma lista de abreviações indicando diferentes línguas de interface aparece um pouco abaixo do banner:

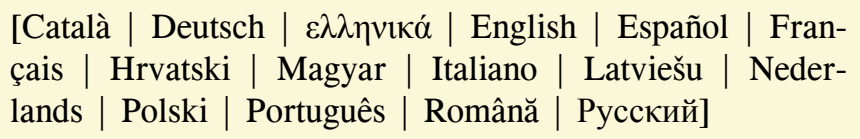

Outra lista de línguas, em forma de janela em cascata, pode ser acessada a partir da sessão baBeLOG do site (Figura 9). A maioria dos websites listaria primeiro o inglês, talvez seguido por francês e espanhol, mas nas variações dessas línguas de interface, desde a fundação doBabels em 2002, o inglês nunca apareceu em posição de destaque, em nenhuma seção do site.

Até 2009, o website do Tlaxcala mostrava uma estratégia semelhante, mas menos radical, com objetivo de relativa desvalorização do status do inglês, mas com destaque ainda para outras línguas dominantes, isto é, o espanhol e o francês (Figura 10).Entretanto, em seu site atual, o inglês vem em primeiro lugar. Ainda assim, esse grupo continua a dar visibilidade para uma série de outras línguas, incluindo tamaxeque e esperanto (Figura 11). 


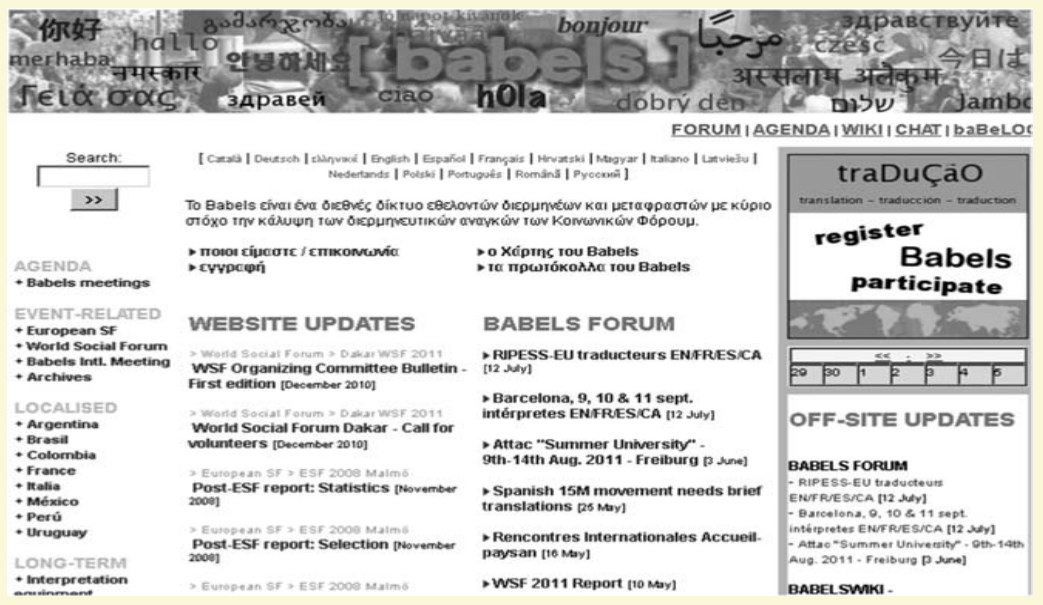

Figura 8. Página inicial doBabels (acesso em 12 de agosto de 2011).

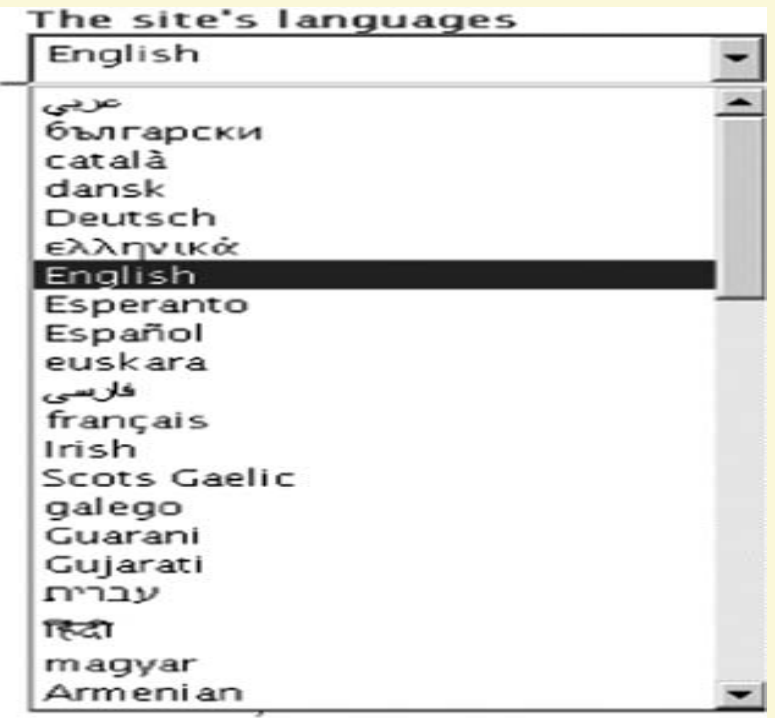

Figura 9.Lista de línguas do site doBabels, acessível naseção baBeLOG (acesso em 12 de agosto de 2011). 


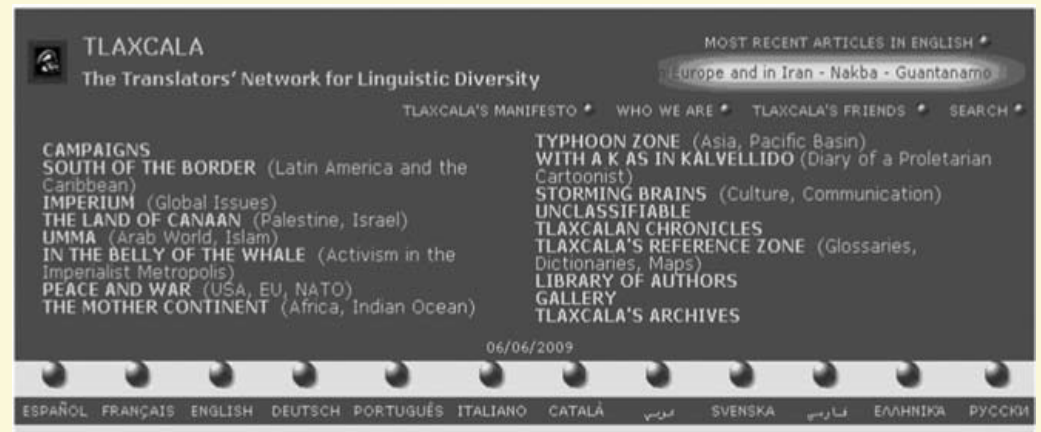

Figura 10.Línguas de interface em uma versão anterior do website do Tlaxcala (2009).

Além disso, para enfraquecer o poder global do inglês, ao colocá-lo mais abaixo na lista de línguas de interface ou ao incluir várias outras línguas, entre outros recursos interessantes, o layout do site do Babels e do Tlaxcala faz conexões globais, celebra a diversidade e enfraquece a hierarquia linguística.

Como pode ser visto na Figura 8, uma breve declaração sobre o Babels aparece logo abaixo da lista de línguas de interface na página inicial. Essa declaração aparece, de forma imprevisível, em diferentes línguas e diferentes momentos, onde se lê: o "Babels é uma rede internacional de intérpretes e tradutores voluntários, cujo principal objetivo é atender às necessidades de interpretação dos Fóruns Sociais”. Essa mudança de línguas em diferentes dias e visitas ao site e a ordem aleatória em que as línguas são listadas, assim como o nível variado de visibilidade dado às diversas línguas em diferentes seções, são parte da mensagem política do Babels. Isso constitui parte de uma estratégia maior projetada para inverter a ordem simbólica ao narrar o cenário linguístico e, consequentemente, cultural, como sendo plural, fluido, diversificado e não hierárquico.

O Babels também se empenha em criar espaços inclusivos para múltiplas vozes em outras áreas de sua atuação. A forma como seus membros interagem - no Wiki, Chat e baBeLOG - representa os 
mesmos princípios de diversidade linguística e fluidez apresentados na entrada do baBeLOG mostrado na Figura 12.

O Tlaxcala inverte a ordem simbólica ao romper o padrão dominante referente ao fluxo de tradução. O padrão dominante, como eles argumentam, é que "não anglófonos são relegados a meros espectadores passivos cujas opiniões não contribuem para a discussão global", porque suas contribuições geralmente não são traduzidas para o inglês e para outras línguas de grande difusão (TALENS, 2010, p. 20). Logo, o Tlaxcala não dá prioridade ao inglês - ou francês ou espanhol - como língua de partida, nem às línguas como árabe, turco e persa, que são tratadas predominantemente como língua de chegada, i.e. receptoras pacíficas do conhecimento político que emana da Europa. As traduções postadas no site são realizadas a partir e para todas as 13 línguas oferecidas, dependendo da seleção feita por aqueles que decidem se voluntariar como tradutores.

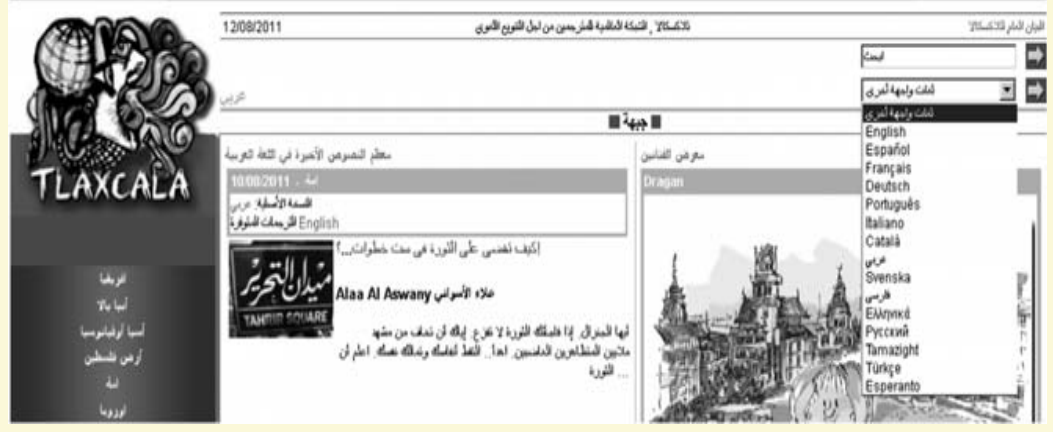

Figura 11.Línguas de interface no site atual do Tlaxcala (acessado em 12 de agosto de 2011). 


\title{
baBeLOG
}

Home page

\section{Athens 2006. The ESF alter-clockwise blog}

24 July 2006, by Maria Brander

\begin{abstract}
by María Brander
What is the ESF? A colleague asked yesterday on the bus back to real-life

Edinburgh, number 25 to Heriot-Watt. Wow, chica. Where could I start?

A Forum is this:

Saturday.

Welcome to Tijuana; tequila, sexo y marihuana.

Bienvenida a Tijuana, bienvenida mi amor...

I will raconte alter-clockwise if you don't mind, so as to capture the "horizontal" spirit of the Forum, in the language I see fit to express each feeling, 278 seminars, conferences, workshops, 104 cultural events, (...)
\end{abstract}

Figura 12. baBeLOG, 2006.

Isso contrasta nitidamente com a prática de grupos que apoiam instituições políticas.Por exemplo, o Instituto de Pesquisa de Mídia do Oriente Médio (MiddleEast Media ResearchInstitute - MEMRI) mantém uma nítida divisão entre as línguas de partida, como árabe, persa e turco, e as línguas de chegada, como inglês, francês, espanhol e hebraico (BAKER, 2010). No contexto da narrativa do MEMRI, que se declara como um grupo ativo na luta contra o terrorismo ${ }^{30}$, essa divisão constrói uma rígida narrativa do mundo, como constituído de dois tipos de protagonistas: "aqueles que representam uma ameaça ao progresso, às sociedades democráticas e que, portanto, precisam ser monitorados muito de perto (por meio da tradução), e aqueles que carregam o fardo de monitorar essas fontes de ameaça à segurança, para proteger o inocente, democrático e civilizado mundo ocidental contra atividades terroristas" (BAKER, 2010, p. 355).Por outro lado, a prática do Tlaxcala constrói uma narrativa de um mundo em que os protagonistas são cidadãos do mundo, com direitos iguais de falar e ser ouvido em

30 "O trabalho do MEMRI apoia diretamente a luta dos Estados Unidos contra o terror", ver: $<$ http://www.memri.org/assistingamerica/ > . (Acesso: 12 ago. 2011). 
qualquer língua desde que haja tradutor voluntário.As traduções não estão enquadradas como ferramenta de monitoramento de comunidades suspeitas, mas como um meio de troca e um desafio à ordem mundial dominante.

\section{Conclusão}

Neste artigo, tentei demonstrar que um número crescente de grupos ativistas de tradutores e intérpretes tem se juntado ao movimento global de justiça desde 1998 e que espaços distintos e autônomos em que vários atores podem experimentar a perspectiva de vislumbrar um mundo novo estão sendo criados. Além de engajar-se na resistência, nas formas de ação altruísta e de fornecer interpretação e tradução voluntárias, este artigo demonstrou que o Babels, o Tlaxcala e os outros grupos discutidos aqui estão cada vez mais tentando configurar um espaço em que desempenhos linguísticos específicos participam, sutilmente, na criação de uma nova situação cultural e de um novo equilíbrio de poderes. Esse não é um espaço estático, mas sim fluido, dinâmico, negociável e em mudança constante. Apesar da depreciação propositada do inglês como uma língua colonizadora, a fluidez e a diversidade têm o objetivo de enfraquecer e dissolver os sinais de hierarquia e separação das línguas, e ainda tudo que essa hierarquia significa em termos de poder e avaliação implícita das diferentes línguas e culturas.

Em razão de colocarem suas habilidades profissionais e linguísticas a serviço de movimentos políticos e se identificarem explicitamente como tradutores e intérpretes, as atividades desses grupos criam tensões dentro do círculo profissional que, por muito tempo, tem sido dominado por um discurso de neutralidade e não engajamento como pré-requisito para comunicação entre as culturas.Ao mesmo tempo, a natureza altruísta de suas contribuições frustra suas tentativas de exercer um papel totalmente político em alguns eventos ativistas. À medida que eles crescem em número e tamanho e desenvolvem suas próprias e novas formas de fazer política, estudiosos da 
tradução e de movimentos sociais deveriam consideraras atividades e esforços desses grupos para desenvolver abordagens teóricas de seus posicionamentos e métodos de prefiguração de modo que possam contribuir de forma produtiva para ambas as áreas.

\section{Referências}

ATTON, C. Reshaping social movement media for a new millennium. Social Movement Studies, v. 2, n. 1, p. 3-15, 2003.

BAKER, M. Translation and Conflict: A Narrative Account. London; New York: Routledge, 2006a.

BAKER, M. Translation and activism: Emerging patterns of narrative community. The Massachusetts Review, v. 47, n. III, p. 462-484, $2006 \mathrm{~b}$.

BAKER, M. Resisting state terror: Theorizing communities of activist translators and interpreters. In: BIELSA,E.; HUGHES,C. W. (Orgs.). Globalization, Political Violence and Translation. Basingstoke: Palgrave Macmillan, 2009, p. 222-242.

BAKER, M. (2010) Narratives of terrorism and security: 'Accurate' translations, suspicious frames. Critical Studies on Terrorism, v. 3, n. 3, p. 347-364, 2010.

BALSALOBRE, L. S., MANUEL JEREZ, J., GARCÍA, E. M.; GUTIÉRREZ, E. R. ECOS: 12 years breaking down the barriers of silence and languages. Tradução do espanhol de A. Martin. In: BOÉRI, J; MAIER, C. (Orgs.). Translation/interpreting and social activism. Granada: ECOS, 2010, p. 7-18.

BOÉRI, J. A narrative account of the Babels vs. Naumann controversy: Competing perspectives on activism in conference interpreting. The Translator, v. 14, n. 1, p. 21-50, 2008. 
BOÉRI, J. Babels, the social forum and the conference interpreting community: Overlapping and competing narratives on activism and interpreting in the era of globalisation. 2009. Tese de doutorado. CTIS, University of Manchester. Manchester, Inglaterra. 2009.

BOÉRI, J.; HODKINSON, S. Babels and the politics of language at the heart of Social Forum. 2005. Disponível em: < http://www.forumsocialmundial.org.br/ dinamic. php?pagina $1 \frac{1}{4}$ babels $>$. Acesso em: 6 abr. 2012).

CARTY, V. Technology and counter-hegemonic movements: The case of Nike Corporation. Social Movement Studies, v. 1, n. 2, p. 129-146, 2002.

CARTY, V.; ONYETT, J. Protest, cyberactivism and new social movements: The reemergence of the Peace movement post 9/11. Social Movement Studies, v. 5, n. 3, p. 229-249, 2006.

DELLA PORTA, D.;MOSCA, L. Build locally, link globally: The Social Forum process in Italy. American Sociological Association, v. 16, n. 1, p. 63-81, 2010.

FLESHER FOMINAYA, C. Autonomous movements and the institutional left: Two approaches in tension in Madrid's anti-globalization network. South European Society and Politics, v. 12, n. 3, p. 335-358, 2007.

HERNADI, P. On the how, what and why of narrative. In: MITCHELL,W. J. T. (Org.). On Narrative. Chicago; London: University of Chicago Press, 1980/1981, p. 197-199.

HODKINSON, S.; BOÉRI, J. (2005) Social Forums after London: The politics of language, Red Pepper. 2005. Disponível em: < http://www.redpepper.org.uk/ Social-forums-after-London-The $>$. Acesso em: 9 mar. 2012).

JURIS, J. Social Forums and their margins: Networking logics and the cultural politics of autonomous space. Ephemera, v. 5, n. 2, p. 253-272, 2005.

LAMPROPOULOU, A. Babels' interpreting policy in the Athens European Social Forum: A socio-political approach to interpreting. In: BOÉRI, J.; MAIER, C. (Orgs.). Interpreting and Social Activism. Granada: ECOS, 2010, p. 28-37. 
MAECKELBERGH, M. Doing is believing: Prefiguration as strategic practice in the alter globalization movement. Social Movement Studies, v. 10, n. 1, p. 1-20, 2011.

MANUEL JEREZ, J.;LÓPEZ CORTÉS, J.;BRANDER DE LA IGLESIA, M. (n.d.) Social commitment in translation and interpreting: A view from ECOS, translators and interpreters for solidarity. Disponível em: <http://cicode-gcubo. ugr.es/ecos/artecos/articuloingles $>$. Acesso em: 11 mar. 2012.

MELUCCI, A. Challenging Codes: Collective Action in the Information Age. Cambridge: Cambridge University Press, 1996.

Notes from Nowhere (Orgs.). We Are Everywhere: The Irresistible Rise of Global Anti-Capitalism. London: Verso, 2003.

NAUMANN, P. Babels and nomad - observations on the barbarising of communication at the 2005 World Social Forum, Communicate! 2005. Disponível em: < http://aiic.net/ViewPage.cfm/page1800.htm>. Acesso em: 27 abr. 2012.

PÉREZ-GONZÁLEZ, L. Intervention in new amateur subtitling cultures: A multimodal account, Linguistica Antverpiensia, 6, p. 67-80, 2007.

TALENS, M. The languages of Tlaxcala: A short history of a longwalk. In: BOÉRI, J.; MAIER, C. (Orgs.). Interpreting and Social Activism. Tradução do espanhol de S. Campbell. Granada: ECOS, 2010, p. 1924.

TARROW, S. The New Transnational Activism. Cambridge: Cambridge University Press, 2006.

Recebido em: 12 de novembro de 2017

Aceito em: 15 de fevereiro de 2018 Publicado em: maio de 2018

Cristiane Roscoe-Bessa. E-mail: crbessa@unb.br.

Flávia Lamberti. E-mail: flavialamberti@gmail.com

Janaína Araújo Rodrigues. E-mail: jana.araujor@gmail.com. 